\title{
Realizing the demand-driven paradigm in vocational education: A case study on vocational high school teaching-industry partnership program
}

\author{
Yuyun Estriyanto * \\ Universitas Sebelas Maret. \\ * Corresponding Author. Email: yuyun.e@staff.uns.ac.id
}

\section{ARTICLE INFO}

\section{Article History}

Received:

9 April 2021;

Revised:

21 June 2021;

Accepted:

24 August 2021;

Available online:

5 November 2021

\section{Keywords}

Conformity;

Demand-driven;

Partnership;

Teaching-industry;

Vocational high school

\begin{abstract}
The teaching-industry partnership program between schools and industry could be a good alternative to be implemented in vocational education. This research aims to describe the collaboration pattern between Vocational High School (VHS) and its industry partner. This research was conducted using the case study qualitative research method. The data were collected through indepth interviews, observations, and documentation. The informants were teachers, the head of the motorcycle-technician department, trainers from the industry, and senior technicians of the motorcycle maintenance workshop selected based on purposive sampling. The results show that in order to operate well, the program requires: 1.) A close relationship between the school and the industry; 2.) Agreement to share knowledge, skills, equipment, and funding between the two parties; and 3.) The willingness of the school to integrate industrial specificity into the learning system. This study also finds that the program just partially aligned with the demand-driven paradigm. Conformity has been realized in terms of preparing graduates' competence following the industry's need, but not yet in terms of the number of graduates required by the company. Any method in increasing the conformity between the labor demand and supply still needs further study.
\end{abstract}

This is an open access article under the $\underline{\mathrm{CC}-\mathrm{BY}-\mathrm{SA}}$ license.

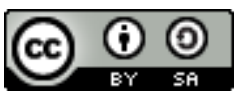

\section{How to cite:}

Estriyanto, Y. (2021). Realizing the demand-driven paradigm in vocational education: A case study on vocational high school teaching-industry partnership program. Jurnal Pendidikan Vokasi, 11(2), 146154. https://doi.org/10.21831/jpv.v11i2.39980

\section{INTRODUCTION}

The alignment of the world of education with work is a problem in many countries. This form of disharmony can be seen from the high unemployment rate. In Indonesia, for example, in May 2019, the national open-unemployment rate was still at $5.01 \%$, while $57.27 \%$ of the working population was working in the informal sector (Suhariyanto, 2019). This disharmony between the world of education and the world of work can also be in the form of a mismatch of education with jobs obtained by graduates (Robst, 2007; Senarath et al., 2017). Therefore, aligning the world of education with the world of work is a must for all countries to develop a healthy national economy.

Alignment is the compatibility between the labor market and those produced by educational institutions. The alignment contains aspects of quality, quantity, location, and time (Slamet, 2014). Quality aspects are related to the level of competence of graduates compared with the needs of the workforce. The quantity aspect is related to the number of graduates compared to needs. The location aspect is related to the geographical position of labor-producing institutions with industries in need. The time aspect is related to the projected time of workforce needs with the production of the workforce. Graduates with excellent competence but present at the wrong time are also issues that must be anticipated (Liu et al., 2012). The World Economy Forum recommends building social 
partnerships to create a match between graduates' skills and the world of work (Klosters, 2014). This partnership will increase the competence of graduates and enable them to obtain better jobs for graduates.

To realize conformity between schools and the world of work, the educational development paradigm must be demand-driven rather than supply-driven. The purpose of education based on the demand-driven paradigm is that the substantial competencies needed by the world of work have been formulated and followed by concrete efforts to produce skilled workers to meet the demands of the world of work (Tugu Jojga, 2018). In reality, the demand-driven paradigm of vocational education cannot yet be fully implemented in most countries' education systems. However, although it is still sporadic, efforts to realize link-and-match between vocational schools and the industrial world is continuing.

One such effort is the teaching industry, which is the industry entering into the educational process in vocational school partners in producing prospective graduates who are ready to work following the competency qualifications required by the industry. The term teaching-industry has the same meaning as industrial vocational school or industrial class used by (Yoto et al., 2019). This kind of school-industry partnership is currently starting to develop under the initiation of some industries. Furthermore, the teaching-industry term has not well known enough in vocational education literature compared to other terms. The term teaching-factory (Alptekin et al., 2001; Chryssolouris et al., 2016; Martawijaya, 2012) is commonly used compared to teaching-industry. Teaching-factory is defined as a learning concept that adopts applied-oriented training practices and approaches that combine learning and working environments from which tangible and relevant learning experiences are obtained (Nanyang Polytechnic, 2021). Abele et al. (2015) and Lamancusa et al. (2008) use the term learning factory to express a learning system that includes the meaning of learning and production simultaneously. Therefore, basically, these terms indicate a similar meaning. The difference is, in the teaching industry, there is a part of learning that is carried out in partner industries, while the teaching-factory concept does not yet contain that meaning.

Explanation of article 15 of Law Number 20 of 2003 concerning the National Education System states that vocational secondary education aims to prepare students, especially to work in specific fields. It was also stated that the form of vocational education at the secondary education level is the Vocational High School (VHS). According to the Indonesian Qualifications Framework (IQF), VHS graduates are at level 2 with a description of specialized competencies consist of: 1.) Being able to carry out a specific task by using tools, information, and work procedures that are commonly used, as well as showing performance with measurable quality under direct supervision; (2) Possess basic operational knowledge and factual knowledge of specific work areas so that they are able to choose available solutions of problems that commonly arise; and (3) Take responsibility for their own work and can be given the responsibility to guide others (President of the Republic of Indonesia, 2003).

The description of Level 2 IQF competencies is very much in accordance with vocational education's objectives, as stated in the National Education System Law, which prepares students to work in specific fields. The Level 2 IQF competency description can only be formed from the learning process that emphasizes real work experience. It should bring students to work, doing the actual work, repeatedly, so that they internalize the skills needed to complete every task in their job. Students' skills then should be evaluated using hands-on or applied performance, that is, based on the student's ability to complete the work (Finch \& Crunkilton, 1999). However, it turns out there are still many graduates who do not get jobs in accordance with their education. High unemployment is the concern of every government because it threatens the economic welfare of its people.

One of the causes of unemployment is the mismatch between supply and labor demand. It might refer to the mismatch of types of competencies, level of education, and the number of workers produced by the educational institutions compared to the industrial needs. Slamet (2014) states that vocational education is economic education. Each program must answer the following three questions appropriately: what to produce, how to produce, and whom. Vocational development planning must be based on a workforce planning approach, not a social demand planning approach, so that graduates are aligned with the needs of the workforce. 
To minimize the school-industry mismatch, the Indonesian Minister of Education for the 1989-1998 period, Prof. Dr. Ing. Wardiman, has launched a link-and-match program between the world of education and the industrial world. Link-and-match is a vocational education paradigm that leads to realizing the relationship and compatibility between educational institutions and the world of work (Djojonegoro et al., 1998). Thus, it is expected that vocational education orientation will no longer be supply-minded but will become more demand-minded (based on market needs). The flagship program to realize the link-and-match paradigm is the dual-system education model, which is then officiated with (Minister of Education and Culture Decree Number 323/U/1997 concerning the Implementation of Dual System Education in vocational high schools.

The minister's decree becomes the legal umbrella for implementing education partnerships between VHS and industry, which refers to the school-industry partnership. Some basic principles of implementing a dual system include: 1.) Each vocational school is required to have a partner industry; (2) Vocational schools apply curricula that are synchronized with partner industries; 3.) Sending students to work for three months to one year in industry, industry sub-divisions, and positions must be relevant to the student's primary competence; and 4.) The evaluation must involve experts from the industry or any professional certification body (Ministry of Education and Culture of the Republic of Indonesia, 1997).

One form of learning concept that brings educational institutions closer to the industrial world is the concept of the teaching industry. The teaching-industry learning model is a solid partnership education product between a vocational school and a partner industry. In this case, the industry entered and colored the learning process in VHS. Aspects that are influenced by the industry include curriculum content, learning, and equipment that have been pegged in reference to certain products or industries. The Ministry of Education and Culture calls the teaching industry as a learning model whose patterns can be described in stages: 1.) Vocational schools work together with industry in the provision of production sites; 2.) The industry transfers knowledge to the vocational school; and 3.) The vocational schools have limited licenses to market the collaborated products (Directorate of Vocational Development of the Republic of Indonesia, 2015). Sakarinto states that the basic concept of the teaching industry is the transfer of a portion of the educational process and the industrial process in a learning design so that the competency-based education occurs (Tugu Jojga, 2018).

From the description above, it can be explained that the concept of teaching-industry in VHS consists of: (1) vocational schools that open themselves to make changes to their learning systems to suit industry needs; (2) partner industries that have the awareness to collaborate with vocational schools to produce the desired workforce qualifications; (3) there is knowledge transfer from partner industries to vocational schools; (4) the unity of educational processes and industrial processes in one learning design; (5) the existence of ongoing cooperation between VHS and industry during the education process takes place. Thus, it is expected that the ongoing education program is a program that is indeed needed by the industry so that the possibility of a miss-match between educational institutions and the world of work can be avoided.

One form of teaching industry currently developing in Indonesia is the emergence of Honda Vocational Schools in producing prospective graduates of Honda motorcycle technicians. Honda, in this case, Astra Honda Motor, cooperates with Vocational High School (VHS) to carry out an education program which developed to produce technicians in the Honda motorcycle maintenance service network (AHASS) in Indonesia. The Honda motorcycle maintenance business market continues to grow over time because millions of Honda motorcycles are always absorbed by the national market each year. Honda also appears to be the leader of the national motorcycle market, so that the official maintenance workshop network must continue to be developed to provide after-sales services for Honda motorcycle owners. The increasing number of Honda workshops requires the availability of technicians who have the competency according to the needs of Honda workshops. It is Honda's concern to prepare a large number of Honda technicians.

This research aims to describe the pattern of cooperation between Honda and vocational school partners in carrying out an education program to prepare Honda motorcycle technicians. This research will reveal the fulfillment of demand-driven and link-and-match paradigms in the education program in terms of cooperation patterns, curriculum, and teaching model. The findings in this study 
could be an alternative model for developing industrial-class vocational schools for other kinds of occupations.

\section{RESEARCH METHOD}

This research uses the case study qualitative research method. The institutions involved were Astra Motor Training Center (AMTC), located in Semarang as a training unit of Honda Motor, VHS Muhammadiyah 1 Surakarta as a vocational school, and Astra Honda Authorized Service Station (AHASS) workshop as the graduate user. AHASS is a network of Honda motorcycle maintenance workshops in Indonesia. Data collection was carried out using in-depth interviews, field observations, and documentation. The informants in this study were instructors of AMTC Semarang, who also act as program administrators respectively, teachers and head department of the Honda Technician Program at VHS Muhammadiyah 1 Surakarta, and the technician's head of the AHASS workshop.

The interview protocol was used as a guide to dig up information and keep the discussion during the interview focused on the research problems. An audio recorder device was used to record the conversation. A phone camera was used to take pictures of important facts during observation. Data validity is conducted using triangulation techniques, both methods, and data sources triangulation. Data validity is also sought by member checking and also by extending the data collection period. The research-finding was reported using explanation-building techniques with chronological reporting methods. That is, in this report, the researcher tries to explain the concept building of the phenomenon and report it coherently following the results of data analysis.

\section{RESULT AND DISCUSSION}

The Teaching-Industry Program Partnership Pattern

Based on data obtained from informants from AMTC and Muhammadiyah 1 VHS, cooperation between Honda as prospective users of VHS Motorcycle Engineering graduates and VHS as providers of motorcycle technician patterns can be formulated. The scheme of the Honda-VHS partnership pattern can be illustrated in Figure 1. The cooperation scheme between Honda and the VHS partner in Figure 1 explains that VHS provides labor graduates required by Astra Honda Motor (AHM). AHM is an industry that has a core business in manufacturing, distributing, and maintaining Honda motorcycles in Indonesia. In this case, AHM is the party that requires skilled motorcycle technicians for after-sale motorcycle maintenance services.

AHM entered into the learning process at VHS partners on the motorcycle technician expertise package. It influenced the learning process, following the expertise and technology that Honda needed in the Honda motorcycle maintenance network (AHASS). AHM, in this case, AMTC, provides training to teachers on the specific competencies desired by Honda. AHM also provides teaching media support, repair manuals, learning modules, and also special tools to VHS partners. Vocational schools send teachers for training in Honda motorcycle maintenance techniques to AMTC. Training for partner VHS teachers is always given regularly, especially every time Honda launches new products on the market.

The output of this collaboration program is graduates with highly skilled Honda motorcycle technicians. Graduates are ready to be employed in the AHASS network that spreads throughout Indonesia. The study also revealed that there are still many graduates who are not absorbed in the AHASS network. According to an informant from AMTC, not all graduates of this program can be absorbed by the AHASS network. For graduates of this kind, they are expected to be entrepreneurs in motorcycle maintenance because, basically, graduates of this program already have competence in motorcycle maintenance for all types and brands of motorcycles. The blue dashed line indicates the indirect benefits for Honda's business. High-skill non-official workshops will handle customers who do not deliver their motorcycle maintenance on the AHASS network. 


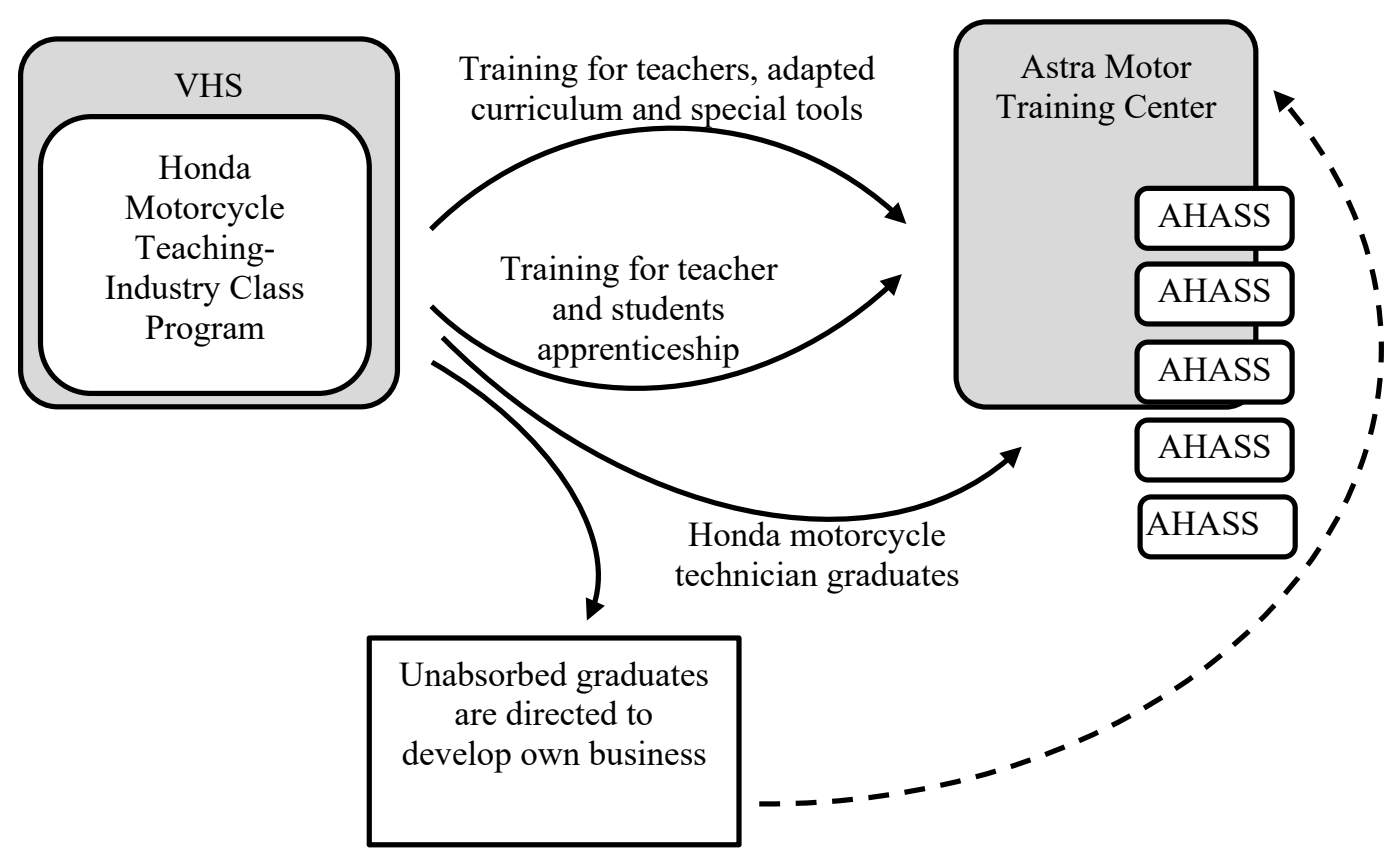

Figure 1. Honda Motor - VHS Cooperation Pattern

In this partnership model, there is a good relationship between Honda requiring graduates and VHS as labor-producing educational institutions. This is in accordance with Kloster's recommendation, which emphasizes the need for social partnerships in the development of vocational education (Klosters, 2014). The link-and-match paradigm is realized by accommodating the competencies along with the special technology desired by Honda in the curriculum of the Honda motorcycle technician education program at the VHS. Thus, the graduates produced by this cooperation program can certainly be employed with the qualifications that Honda indeed needs.

From this partnership program, the benefits gained by VHS include large opportunities for graduates to be recruited in the AHASS workshop network, apprenticeship opportunities for students, and graduates who have high competence in maintaining Honda motorcycle products so that they are capable of doing business in motorcycle maintenance services. The advantage for AHM is the strong core business, which is high motorcycle sales, due to the availability of skilled technicians for the maintenance of its products in the community, either through AHASS authorized workshops or by independent workshops.

In this program, the demand-driven paradigm works well because the program arises based on the needs of workers with special qualifications desired by the industry. This kind of school and industry partnership is highly recommended for increasing competence and conforming to industry needs (Mbah et al., 2018; Watters et al., 2016). However, because Honda absorbs not all graduates, it can be concluded that the realization of the link-and-match in this program is still partial, especially in the aspect of quality. While in the aspect of quantity, namely the number of labor needs, has not been fully realized.

\section{The Teaching-Industry Program Curriculum}

The integration of Honda's content into the partner VHS curriculum, which was initially referred to as the national curriculum, can be described schematically as Figure 2. In the illustration, the blue circles (i.e., $\mathrm{A}, \mathrm{B}$, and $\mathrm{C}(\mathrm{C} 1, \mathrm{C} 2, \mathrm{C} 3))$ represent the national curriculum content referred by the VHS in case it does not cooperate with Honda. The orange circle is Honda's specialty. Most of the curriculum required by Honda has been included in group $\mathrm{C}$ subjects in the national curriculum (intersection between the big blue circle and the orange circle). However, there is an orange circle area that is not covered in the blue circle. This area represents the contents of Honda's curriculum, which has not been covered in group $\mathrm{C}$ subjects in the national curriculum for motorcycle technicians. This area illustrates Honda's special technological content, such as PGMFI, Combi Brake System, 
Idling Stop System, etc. The combination of the standard curriculum for motorcycle technicians according to the national curriculum and the Honda content curriculum becomes the curriculum content of the Honda Vocational School curriculum.

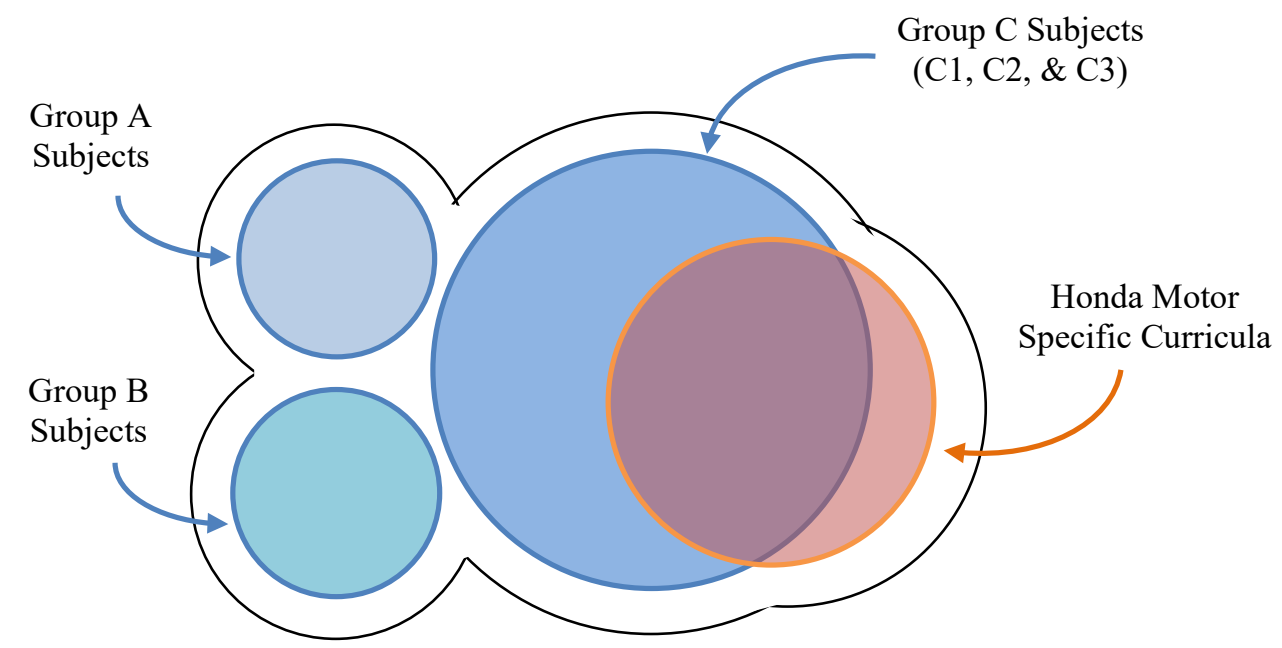

Figure 2. The Curriculum Structure of Honda Motor Technician VHS Program

The curriculum of the Honda - VHS motorcycle technician education program is a national curriculum of motorcycle maintenance technician expertise. However, the curriculum was modified to include special technologies and competencies needed to handle Honda motorcycle maintenance. Finch and Crunkilton (1999) states that the curriculum of vocational education institutions must be aligned closely with employers' needs, and schools must provide workplace-relevant learning for students. Thus, it can be said that the collaborative curriculum model between Honda and VHS is a good curriculum development model for vocational education institutions. Sohimi et al. (2019) recommends that education providers must be open and create a platform to accept industry opinions. Both parties have to share their resources, including skills, knowledge, facilities, and funding.

As a part of the national education program, VHS that implements this partnership program is seen using the national curriculum as a reference. However, it also accommodated Honda's special needs. Thus, the graduates of this program are graduates who have competence as standard motorcycle technician graduates, but they have more capability to maintain Honda motorcycles. Indonesian government gives flexibility for schools to develop their specific institutional unit level curriculum. Billet (2011) calls this curriculum a bottom-up curriculum, a curriculum that an educational institution initiated.

\section{The Teaching and Learning Process}

Learning is developed to resemble the conditions of the work environment. The similarity can be seen from various aspects found in vocational learning workshops as places for learning, AHASS workshops as workplaces where graduates will work, and workshops at AMTC. Various aspects of the synchronized learning environment include: 1.) The type of vehicle used as a teaching aid; 2.) Type of equipment used for work; 3.) Equipment layout and zoning work; 4.) Workshop color combinations; 5.) Design, type and color of clothing used for work; and 6.) Type of work handled.

The practical training program for students participating in the Honda motorcycle technician education program is carried out on the AHASS network. In the period of the practical training program, students participate in jobs handling customer motorcycle maintenance. This is to provide more hands-on experience about the world of work after students graduate. During the practical training program, students are supervised by experienced technicians in the AHASS workshop network. In the third year, the competency test was carried out by involving experienced Honda 
technicians from AHASS. Honda instructors came to the vocational school to carry out the performance test following Honda standards.

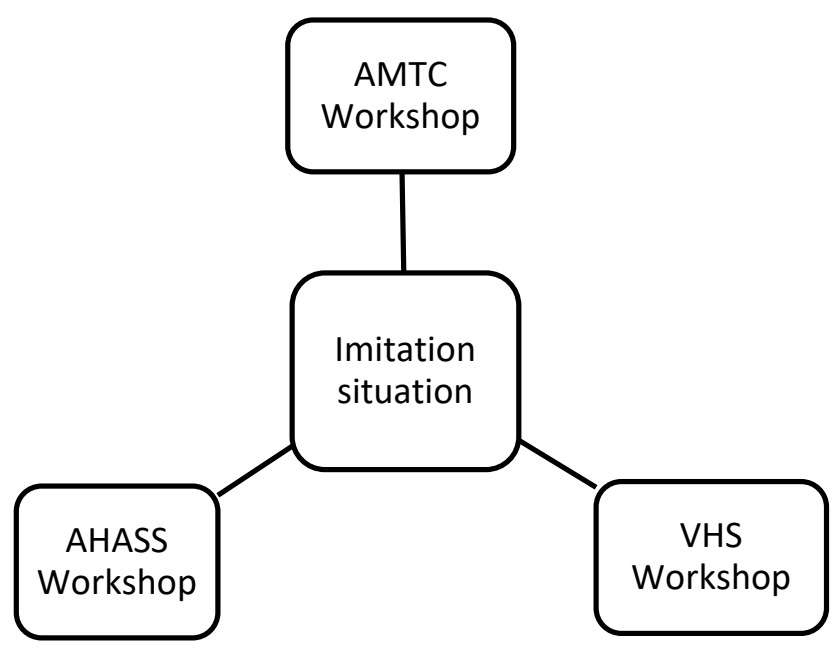

Figure 3. Similarities between VHS Workshop and the AHASS Workshop

The practical training program for students participating in the Honda motorcycle technician education program is carried out on the AHASS network. In the period of the practical training program, students participate in jobs handling customer motorcycle maintenance. This is to provide more hands-on experience about the world of work after students graduate. During the practical training program, students are supervised by experienced technicians in the AHASS workshop network. In the third year, the competency test was carried out by involving experienced Honda technicians from AHASS. Honda instructors came to the vocational school to carry out the performance test following Honda standards.

The learning process in this partnership program was developed to resemble the conditions of the work environment, both the conditions of the workshop, the atmosphere, the layout, and the equipment. Karre et al. (2019) states that the dramatic change of the industrial world requires graduate agility that can be minimized through a close-to-reality learning factory environment. The teaching method that has been carried out in this partnership program is also appropriate with the Prosser and Allen (1950) theorem that vocational education will be efficient if the environment in which students are trained is a replica of the environment in which students will work after graduation. The theorem also mentions that effective vocational education can only be given where training tasks are carried out in the same manner, tools, and machinery as used in the workplace. This can be seen in the similarity of work procedures, tools, and visual aids between Honda and VHS partners. By using the same facilities, students are accustomed to thinking and working as needed in the real world of work.

Confronting the students directly to any task from the workplace enables the formation of students' working and thinking habits as needed in later work. Thus, students truly gain meaningful learning experiences. Teaching is carried out by persons who are trained directly by trainers from the workplace where prospective graduates will work. It fits with Prosser's theorem that vocational education will be effective if the teacher has had successful experiences in applying skills and knowledge in the operations and working processes that they will train. This is also in line with other points of the Prosser theorem that a reliable source for the content knowledge of training at a particular occupation is from the experience of the occupational experts. Apprenticeship students at AHASS workshops will also significantly provide meaningful experiences for students. Eichhorst et al. (2013) states that apprenticeship programs combined with institutional learning are more effective than purely school-based vocational education. 


\section{CONCLUSION}

The collaboration program between VHS and Honda Motor is a good practice of vocational education based on the demand-driven paradigm, especially at the secondary education level. Linkand-match is well realized in terms of preparing the competencies of graduates according to the company's need, but the number of workforce needs and the number of graduates produced by partner schools has not been matching. Graduates who are not absorbed in the company's business network still have the opportunity to work or set up independent businesses in the same business field, namely in the field of motorcycle maintenance outside the company's official network. A close relationship must be established between the school and the industry to carry out this partnership program. One party is the other party's partner and vice versa. Both parties must agree to share knowledge, skills, equipment, and funding between them. Schools must be open and accommodate industrial needs to be integrated into the learning system in schools.

\section{ACKNOWLEDGMENTS}

Honda Motor Company, Ltd. is an automotive industry based in Japan. Astra Honda Motor is the sole agent of Honda brand holders for motorcycle production in Indonesia. AHASS is a subsidiary of Astra Honda Motor for the Honda motorcycle maintenance service network. The names of Honda, Astra Honda Motor, and AHASS belong to their respective owners.

\section{REFERENCES}

Abele, E., Metternich, J., Tisch, M., Chryssolouris, G., Sihn, W., ElMaraghy, H., Hummel, V., \& Ranz, F. (2015). Learning factories for research, education, and training. Procedia CIRP, 32, 1-6. https://doi.org/10.1016/j.procir.2015.02.187

Alptekin, S. E., Pouraghabagher, R., McQuaid, P., \& Waldorf, D. (2001). Teaching factory. ASEE Annual Conference and Exposition, 9463-9470. https://doi.org/10.18260/1-2--9863

Billet, S. (2011). Vocational education: Purposes, traditions and prospects. Springer. https://doi.org/10.1007/978-94-007-1954-5

Chryssolouris, G., Mavrikios, D., \& Rentzos, L. (2016). The Teaching Factory : A Manufacturing Education Paradigm. Procedia CIRP, 44-48. https://doi.org/10.1016/j.procir.2016.11.009

Direktorat Pembinaan SMK Republik Indonesia. (2015). Panduan pelaksanaan teaching factory. Kementerian Pendidikan dan Kebudayaan Republik Indonesia. http://repositori.kemdikbud.go.id/18290/1/Panduan_Pengembangan_TeFa.pdf

Djojonegoro, W., Slamet, S., Pakpahan, J., \& Widyowatie, D. (1998). Pengembangan sumber daya manusia melalui Sekolah Menengah Kejuruan (SMK). Jayakarta Offset.

Eichhorst, W., Rodríguez-Planas, N., Schmidl, R., \& Zimmermann, K. F. (2013). A roadmap to vocational education and training systems around the world. IZA Discussion Paper No. 7110. https://ssrn.com/abstract=2199793

Finch, C. R., \& Crunkilton, J. R. (1999). Curriculum development in vocational and technical education. planning, content, and implementation (5th ed.). Allyn and Bacon, Inc.

Karre, H., Hammer, M., \& Ramsauer, C. (2019). Building capabilities for agility in a learning factory setting. Procedia Manufacturing, 31, 60-65. https://doi.org/10.1016/j.promfg.2019.03.010

Kementerian Pendidikan dan Kebudayaan Republik Indonesia. (1997). Keputusan Menteri Pendidikan dan Keudayaan Republik Indonesia Nomor 323/U/1997 tentang Pendidikan Sistem Ganda. Kementerian Pendidikan dan Kebudayaan Republik Indonesia.

Klosters, D. (2014). Matching skills and labour market needs: Building social partnerships for better skills and better jobs. World Economic Forum Global Agenda Council on Employment, 1-28. https://www3.weforum.org/docs/GAC/2014/WEF_GAC_Employment_MatchingSkillsLabou 
rMarket_Report_2014.pdf

Lamancusa, J. S., Zayas, J. L., Soyster, A. L., Morell, L., \& Jorgensen, J. (2008). The learning factory: Industry-partnered active learning. Journal of Engineering Education, 97(1), 5-11. https://doi.org/10.1002/j.2168-9830.2008.tb00949.x

Liu, K., Salvanes, K. G., \& Sørensen, E. (2012). Good skills in bad times: Cyclical skill mismatch and the long-term effects of graduating in a recession. European Economic Review, 84, 6820. https://doi.org/10.1016/j.euroecorev.2015.08.015

Martawijaya, D. H. (2012). Developing a teaching factory learning model to improve production competencies among mechanical engineering students in a vocational senior high school. Journal of Technical Education and Training, 4(2), 45-56. https://publisher.uthm.edu.my/ojs/index.php/JTET/article/view/637

Mbah, C. O., Obi, C. U., Ehimen, T. E., \& Onyebuenyi, P. N. (2018). Improving school-industry partnership in skill development of TVET students for matching skill demand in Anambra State. 2nd Annual National Conference of Centre for Technical and Vocational Education, Training and Research (CETVETAR). https://www.researchgate.net/profile/OnyebuenyiPromise-N/publication/326058755_IMPROVING_SCHOOL-

INDUSTRY_PARTNERSHIP_IN_SKILL_DEVELOPMENT_OF_TVET_STUDENTS_FO R_MATCHING_SKILL_DEMAND_IN_ANAMBRA_STATE_Theme_Improving_TVET Quality_for_Matching_Skills_Demand_

Nanyang Polytechnic. (2021). Innovative teaching and learning. Nyp.Edu.Sg. https://www.nyp.edu.sg/schools/sdm/innovative-teaching-and-learning.html

Presiden Republik Indonesia. (2003). Undang-Undang Republik Indonesia Nomor 20 Tahun 2003 tentang Sistem Pendidikan Nasional. http://simkeu.kemdikbud.go.id/index.php/peraturan1/8uu-undang-undang/12-uu-no-20-tahun-2003-tentang-sistem-pendidikan-nasional

Prosser, C. A., \& Allen, C. R. (1950). Vocational Education in a Democracy. Century Company.

Robst, J. (2007). Education and job match: The relatedness of college major and work. Economics of Education Review, 26(4), 397-407. https://doi.org/10.1016/j.econedurev.2006.08.003

Senarath, S. A. C. L., Patabendige, S. S. J., \& Amarathunga, S. (2017). Sri Lankan graduate labour market: A status mismatch. Journal of Economics, Business and Management, 5(1), 63-68. https://doi.org/10.18178/joebm.2017.5.1.487

Slamet, P. H. (2014). Kebijakan pendidikan kejuruan: Refleksi kritis dan koreksi. UNY Press.

Sohimi, N. E., Affandi, H. M., Rasul, M. S., Yasin, R. M., Nordin, N., \& Adam, S. (2019). Malaysian industrial collaborations for skills development in 4th industrial revolution. Journal of Technical Education and Training, 11(3), 63-72. https://doi.org/10.30880/jtet.2019.11.03.009

Suhariyanto, S. (2019). Berita resmi statistik 6 Mei 2019. Badan Pusat Statistik. https://www.bps.go.id/press-release/2019/05/06/234/berita-resmi-statistik.html

Tugu Jojga. (2018). Teaching industry, ladang investasi masa depan. Kumparan.Com. https://kumparan.com/tugujogja/teaching-industry-ladang-investasi-masa-depan

Watters, J. J., Pillay, H. K., \& Flynn, M. (2016). Industry-school partnerships: A strategy to enhance education and training opportunities. Queensland University of Technology.

Yoto, Y., Marsono, M., Irdianto, W., \& Basuki, B. (2019). Industrial class with work based learning approach as alternative to increase educational quality in vocational high school. Proceedings of the 2nd International Conference on Vocational Education and Training (ICOVET 2018), 242, 174-176. https://doi.org/10.2991/icovet-18.2019.44 